IZA DP No. 10104

The “Entrepreneurial Boss" Effect on Employees' Future Entrepreneurship Choices:

A Role Model Story?

Vera Rocha

Mirjam van Praag

July 2016 


\title{
The "Entrepreneurial Boss" Effect on Employees' Future Entrepreneurship Choices: A Role Model Story?
}

\author{
Vera Rocha \\ Copenhagen Business School \\ and IZA \\ Mirjam van Praag \\ Copenhagen Business School \\ and IZA
}

Discussion Paper No. 10104

July 2016

\author{
IZA \\ P.O. Box 7240 \\ 53072 Bonn \\ Germany
}

Phone: +49-228-3894-0

Fax: +49-228-3894-180

E-mail: iza@iza.org

Any opinions expressed here are those of the author(s) and not those of IZA. Research published in this series may include views on policy, but the institute itself takes no institutional policy positions. The IZA research network is committed to the IZA Guiding Principles of Research Integrity.

The Institute for the Study of Labor (IZA) in Bonn is a local and virtual international research center and a place of communication between science, politics and business. IZA is an independent nonprofit organization supported by Deutsche Post Foundation. The center is associated with the University of Bonn and offers a stimulating research environment through its international network, workshops and conferences, data service, project support, research visits and doctoral program. IZA engages in (i) original and internationally competitive research in all fields of labor economics, (ii) development of policy concepts, and (iii) dissemination of research results and concepts to the interested public.

IZA Discussion Papers often represent preliminary work and are circulated to encourage discussion. Citation of such a paper should account for its provisional character. A revised version may be available directly from the author. 


\section{ABSTRACT \\ The "Entrepreneurial Boss" Effect on Employees' Future Entrepreneurship Choices: A Role Model Story?}

Both organizational and sociological approaches in entrepreneurship research highlight the importance of social context in shaping individual preferences for entrepreneurship. An influential contextual factor that has not been studied in entrepreneurship research is one's boss at work. Do entrepreneurial bosses contribute to their employees' decisions to become entrepreneurs themselves? Using Danish register data of newly founded firms and their entrepreneurs and employees between 2003 and 2012, and employing methods that allow causal inferences, we show that entrepreneurial bosses indeed affect their employees' future entrepreneurship choices, especially if both boss and employee are female. We investigate two alternative underlying mechanisms that may shape the (female) boss' influence on (female) workers' entrepreneurship decisions. Our results consistently suggest that entrepreneurial bosses may act as role models for the entrepreneurship activities of their employees, especially between pairs of female bosses and female employees. We do not find any evidence on female bosses acting as "queen bees" at the workplace. Female entrepreneurial bosses may, thus, act as a lever to reducing the gender gaps in entrepreneurship rates.

JEL Classification: L26, J24, J16

Keywords: entrepreneurship, role models, gender gaps, female leadership

Corresponding author:

Mirjam van Praag

Copenhagen Business School

Kilevej $14 \mathrm{a}$

2000, Frederiksberg

Denmark

E-mail:mvp.ino@cbs.dk 


\section{INTRODUCTION}

Entrepreneurial activity has been a source of long-lasting debates among scholars, where contextual and dispositional factors are often proposed as explanations for individuals' choice for entrepreneurship (Sørensen, 2007). Empirical tests indeed support organizational and sociological approaches advocating that (social) context - especially inside organizations shapes one's likelihood to become an entrepreneur (Nanda and Sørensen, 2010; Sørensen and Fassioto, 2011, Sørensen and Sharkey, 2014), above and beyond any dispositional factors, such as risk taking preferences, ability, competitive attitudes or entrepreneurial self-efficacy - where typically women score lower than men (Thébaud, 2010; Charness and Gneezy, 2012, Kacperczyk, 2012). However, women's representation in business start-ups and ownership remains remarkably low (OECD, 2014), which suggests that dispositional traits are not unimportant.

Gender-differentiated perceptions about entrepreneurial activity can also contribute to gender gaps in the likelihood of becoming an entrepreneur. Whether driven by individual disposition, or social norms and shared cultural beliefs that associate business ownership activity to men and stereotypically masculine traits, entrepreneurship rates are lower among women (Thébaud, 2010). Recent studies propose that contextual factors may lessen the effects of such gender-differentiated perceptions (Thébaud, 2015), including those able to raise women's selfconfidence and self-efficacy, such as sharing an entrepreneurial experience with a female friend (Field et al., 2016).

Building on this emerging discussion and on recent research investigating the role played by women in top management teams for female subordinates in their organizations (e.g., Cohen and Broschak, 2013; Srivastava and Sherman, 2015; Foss and Lyngsie, 2016), we theorize (and 
empirically evaluate) that an individual's interaction with an entrepreneurial boss is a key contextual factor shaping the propensity to enter entrepreneurship, especially when both boss and employee are female. As every employee knows, bosses are a non-negligible factor in their lives, possibly not only affecting their current productivity, activities and choices, as recently demonstrated by Lazear, Shaw, and Stanton (2015), but also shaping their future choices and outcomes. ${ }^{1}$ Our study is, in part, inspired by Lazear, Shaw, and Stanton (2015), and uses similar techniques to investigate how, and through which mechanisms, employees' future entrepreneurship choices are affected by their direct bosses (who are entrepreneurs themselves).

On top of this, our study connects three (yet largely separate) streams of research (on which we will elaborate in the next Section). The first theorizes and empirical validates that entrepreneurs are born in, and learn from, existing organizations (e.g., Gompers, Lerner, and Scharfstein, 2005; Sørensen and Fassioto, 2011). In this stream of research, an increasing number of organizational features (or contextual factors), such as hierarchical structures (Sørensen and Sharkey, 2014) and the interaction with peers with certain characteristics or experiences (Nanda and Sørensen, 2010), have been shown to influence employees' outcomes in the firm and their choices for certain occupations, such as entrepreneurship.

The second stream of research that we build on is the body of theory and evidence about the role of female leadership in employees' outcomes inside organizations. Recent studies suggest that female bosses (e.g., managers, supervisors, CEOs) may have a different effect on employees' wages and promotion chances, especially on these of female employees (Bednar and Gicheva, 2014; Srivastava and Sherman, 2015). In this stream of research, role modeling often

\footnotetext{
${ }^{1}$ Goodall, Kahn, and Oswald (2011) and Bednar and Gicheva (2014) are among the recent studies investigating the effects of "bosses" (supervisors and leaders) on workers, and offer evidence on very particular settings where workers' performance can be measured more accurately, such as professional sports (e.g., basketball, soccer, softball, and volleyball). Dahl, Dezsö, and Ross (2012), in turn, show how employees' wages are affected by the transition of the (male) CEO to fatherhood.
} 
emerges as a candidate mechanism, with female board members being able to influence employees' values, visions, and goals, and potentially inspiring and supporting higher achievements among lower-ranked women in the firm. In the other extreme, female bosses may be categorized as "queen bees", when they favor male workers or discriminate female employees. To the best of our knowledge no study has analyzed how this organizational feature impacts on employees' entrepreneurship choices. However, a relevant stream of research highlights the importance of (same gender) role models for an individual's choice for entrepreneurship (Bosma et al., 2012; Greene, Han, and Marlow, 2013; Lindquist, Sol, and van Praag, 2015), typically in other contexts than organizations. This constitutes the third source of inspiration of our study. ${ }^{2}$

Studying the effect of bosses on employee choices has methodological challenges. Not only do employers select their employees, possibly based on unobserved characteristics, but employers also shape their firms into organizations that influence the choice and behavior of employees. Moreover, the opposite is also true: employees may select bosses and firms that are particularly suitable for them. All these choices may be driven by characteristics and factors unobserved by the researcher. If one does not take this non-random assignment of employees to bosses (and vice versa) into account in the empirical methodology, the estimated effect of bosses on employees' entrepreneurship choices may be biased due to identification issues (see Lazear, Shaw, and Stanton, 2015).

Our study is based on register data for Denmark and relies on methods that take into account unobserved characteristics of the employee and their boss, and the possible correlation between these unobserved characteristics. We analyze the labor market transitions of about

\footnotetext{
${ }^{2}$ This third stream of research is to some extent connected to the one on peer effects in entrepreneurship (e.g., Giannetti and Simonov, 2009; Kacperczyk, 2013).
} 
89,000 full-time workers hired by 13,931 entrepreneurs of newly founded workplaces. Our results indicate that working for an entrepreneurial boss of the same gender increases an individual's likelihood of entering entrepreneurship afterwards. This effect is especially strong for women.

We investigate to what extent this result is driven by female entrepreneurial bosses acting as role models, and not as "queen bees". We do not find any evidence that female bosses create a relatively more hostile or unfriendly environment for female employees (e.g., larger gender wage gaps or higher risks of displacement) that could drive their decision to leave wage employment towards entrepreneurship. Instead, our results consistently show that female entrepreneurial bosses may act as mentors, role models, and a source of encouragement for the entrepreneurship activities of their female employees, helping attenuating gender-based perspectives and stereotypes related to entrepreneurship activity.

\section{ENTREPRENEURIAL BOSSES, GENDER, AND EMPLOYEES' CHOICES FOR ENTREPRENEURSHIP}

The idea that employees' decision to become entrepreneurs in the future may be affected by their current boss - who is an entrepreneur her or himself - is grounded in two key established, yet largely separate, streams of work. The first documents that entrepreneurial aspirations are often formed while individuals are working for an existing firm, where they can accumulate several types of capital (e.g., human, social, financial), identify opportunities, and learn about the entrepreneurial process. This line of research has not yet investigated the role of entrepreneurial bosses. The second argues that women in top management teams can influence the gender gaps in wages and promotion chances inside organizations, and often proposes that female leaders 
may act as role models among their female employees. However, employees' outcomes outside the organization, such as the decision to become an entrepreneur, have been overlooked by this second stream of investigation.

We combine these two lines of arguments to investigate whether, and through which mechanisms, entrepreneurial bosses can affect the future entrepreneurship activities of their employees. We argue (and test) that the key mechanism underlying this result is that of role modeling. This premise is further motivated by a third, still emerging, line of research on role models in the context of entrepreneurship. Even though role models have been proposed as agents of change for decades - and consequently as a meaningful policy instrument - by being able to change individuals' motivations and perceptions of self-efficacy (Scott and Twomey, 1988; Scherer et al, 1989; Krueger and Brazeal, 1994), there is almost no published research on entrepreneurial role models (see Bosma et al., 2012). Most of the existing research has focused on entrepreneurial role models inside the family (Greene, Han, and Marlow, 2013; Hoffman, Junge, and Malchow-Møller, 2015; Lindquist, Sol, and van Praag, 2015). ${ }^{3}$

Nevertheless, the other two lines of analysis introduced above not only indicate that role models can also be found inside organizations, but also that the role of (female) bosses on employees' outcomes and career choices deserves further investigation. We articulate these three research strands, which will form the basis for the development of our hypotheses on the effect of entrepreneurial bosses on employees' future entrepreneurship choices.

\footnotetext{
3 A parallel line of investigation has looked at peer effects in entrepreneurship (Nanda and Sørensen, 2010; Kacperczyk, 2013; Field et al., 2016).
} 


\section{Organizations as Fonts of Entrepreneurs}

Most entrepreneurs are born in existing organizations (Bhide, 1994). The decision to establish a new venture is often made while individuals are employed in established firms, where they acquire and accumulate knowledge, skills, and social capital (Sørensen and Fassiotto, 2011). Indeed, incumbent firms may be arenas for learning about the entrepreneurial process (Gompers, Lerner, and Scharfstein, 2005; Phillips, 2005). However, the study of entrepreneurship phenomena has, for a long time, been largely disconnected from the study of organizations. This detachment is quite unfortunate, given that entrepreneurial transition is to a large extent an organizational and a mobility process (Sørensen and Fassiotto, 2011; Sørensen and Sharkey, 2014).

Recently, increasing evidence has been developed showing that workplaces play an important role in this entrepreneurial process. The organization is a source of interpersonal connections and possibly reputation and legitimation, both being highly valuable for future entrepreneurship (Shane and Cable, 2002; Nanda and Sørensen, 2010). Past employment affiliations of new venture founders may influence their ability to pursue riskier strategies, to secure venture capital funding, and to identify new market opportunities (Burton, Sørensen, and Beckman, 2002; Sørensen and Phillips, 2011).

Organizational structure plays a particularly important role. As a general pattern, empirical evidence shows that as organizations grow and age, their workers tend to be less prone to leave paid employment for entrepreneurship (e.g., Dobrev and Barnett, 2005; Gompers, Lerner, and Scharfstein, 2005; Sørensen and Phillips, 2011; Kacperczyk, 2012). The narrowness of the definition of jobs and roles within organizations also influences the likelihood of pursuing entrepreneurship: broader (narrower) sets of experiences lead to more balanced (more 
specialized) skill sets (Sørensen, 2007), thereby increasing (decreasing) the likelihood of entrepreneurship according to the "Jack-of-All-Trades" theory of entrepreneurship (Lazear 2005; Lazear and Gibbs, 2015). In the same line of reasoning, employees in entrepreneurial firms may acquire diverse and broad skills by a less stringent division of labor in such firms where (the few available) resources are often employed in diverse ways. Thus, the engagement in a wider set of tasks and a closer interaction with the entrepreneur induce smaller firms to be more effective at transmitting pro-entrepreneurial attitudes and capabilities to their employees than larger firms (Hyytinen and Maliranta, 2008; Parker, 2009; Elfenbein, Hamilton, and Zenger, 2010; Sørenson and Phillips, 2011; Rocha, Carneiro, and Varum, 2015).

Workplaces may also be training grounds for entrepreneurship through the interaction with peers with prior entrepreneurial experience. Nanda and Sørensen (2010) show that coworkers who were entrepreneurs before may increase the entrepreneurial motivation of their peers, especially of those who had less exposure to entrepreneurship in other aspects of their lives (e.g., in the family or in the region where they live). They find significant peer effects regardless of the success of coworkers' entrepreneurial experiences.

Organizational features that are (also) highlighted as key determinants of motivating workers' entry into entrepreneurship are, among others, bureaucracy, the shape of firm hierarchies, and the consequent wage inequalities (Sørensen, 2007; Sørensen and Sharkey, 2014). The structure of inequality and the lack of advancement opportunities within a firm may induce mobility between firms, or even a preference for entrepreneurship, as a means of achievement. This result introduces our next discussion on gender inequalities within organizations. 


\section{Female Leaders and Gender Gaps Inside Organizations}

Employment contexts are one of the primary structural arrangements that recreate ordinal status rankings of individuals by gender. Gender inequalities within organizations - also referred to as gender hierarchies (Phillips, 2005) - have been widely discussed for decades, with women being documented as a disadvantaged group, no matter whether the outcome is hiring, wages, promotions, or turnover (e.g., Blau and Devaro, 2007; Goldin, 2014; Kunze and Miller, 2014).

A quite recent line of investigation has analyzed how the presence of women at the top of (mostly large) corporations may influence gender gaps, in the sense of narrowing women's relative disadvantages and breaking the so-called "glass ceiling" that is blocking female workers" career progress (Cardoso and Winter-Ebmer, 2010; Matsa and Miller, 2011; Hensvik, 2014). However, no consensus has been reached yet regarding the hypothesis that female-led firms are female friendly, as both positive and negative spillovers from female leaders have been documented (e.g., Smith, Smith, and Verner, 2013; Bednar and Gicheva, 2014; Kunze and Miller, 2014).

On the one hand, women in higher ranks may act as "queen bees" and (intentionally) hinder the career progress of female workers in lower levels of the job ladder. Women who have reached the top ranks of the company may set more flexible standards for promotion for male workers (Lyness and Heilman, 2006), or overestimate the true quality of male candidates (Bagues and Esteves-Volart, 2010), which implies that lower-ranked women have to work relatively harder and face stricter standards than their male counterparts before being promoted. This "queen-bee syndrome" may be especially likely among women reaching the top ranks in male-dominated occupations and/or industries (Bednar and Gicheva, 2014), consistent with the 
view that female leaders may just be "cogs in the machine" (Maume, 2011; Srivastava and Sherman, 2015).

On the other hand, several studies have suggested that female bosses may be agents of change, able to transform social norms, by serving as mentors and role models. First, because employers face imperfect information about worker productivity, they may rely on certain group characteristics, such as gender, as signals of individual performance and ability. For this reason, female bosses (e.g., CEOs, managers, supervisors) might be better able at inferring other women's unobserved productivity, hence reducing statistical discrimination towards female workers (e.g., Cohen and Huffman, 2007; Cohen and Broschak, 2013; Smith, Smith, and Verner, 2013; Hensvik, 2014).

Second, theories of taste-based behavior of leaders also predict that a larger representation of women at the top of the occupational hierarchy may reduce a gender bias (towards male workers) in the selection of employees, diminish gender wage gaps, and provide more opportunities for women to be promoted, which has been referred to as the "women helping women hypothesis" (Lazear and Rosen, 1990; Cardoso and Winter-Ebmer, 2010; Giuliano, Levine, and Leonard, 2011; Cohen and Broschak, 2013; Hensvik, 2014). Beside tastebased theories, efficiency-based theories also postulate that employers may prefer and favor workers of the same type (e.g., race or gender) because of reduced communication costs and consequent efficiency gains (Alesina and La Ferrara, 2005; Forbes et al., 2006; Giuliano, Levine, and Leonard, 2011).

Finally, it is believed that women who break traditional gender roles in the labor market can encourage other women to invest in similar career paths, and enhance female workers' overall efforts (Cohen and Huffman, 2007; Cohen and Broschak, 2013; Hensvik, 2014). Female 
leaders may be better mentors for lower-ranked women (Athey, Avery, and Zemsky, 2000; McPherson, Lynn, and Cook, 2001), act as role models, and even contribute to the formation of new spinoffs mimicking the organizational routines - and specially the gender hierarchies - of the firms they run, which may indirectly facilitate women's success in new firms (Phillips, 2005).

Despite the increasing debate and growing number of empirical analyses on the effect of female leaders on gender gaps within organizations, we still lack evidence on the potential effect of female leaders on women's entrepreneurial behavior - and, consequently, on entrepreneurship differentials between men and women. We may expect female entrepreneurial bosses to increase the entrepreneurial motivation of their female workers, either by acting as "queen bees" or role models. While in the former case women may leave existing organizations and become entrepreneurs due to limited career advancement opportunities and discrimination (Buttner and Moore, 1997; Hughes, 2003), the latter scenario may lead to a more pulled-nature female entrepreneurship. In this case, female entrepreneurs with close interactions with female employees may play a key role in demystifying the entrepreneurial process, increasing the employee's self-confidence, giving them the opportunity of learning about and inspiring them towards entrepreneurship. As a result, existing organizations may spawn new entrepreneurs through an additional mechanism, yet barely studied: by providing their workers with entrepreneurial role models via the interaction with entrepreneurial bosses.

\section{Role Models in Entrepreneurship}

The media and policy discussions pay increasing attention to role models as an influential factor for the choice of an entrepreneurial career. However, empirical research aimed at establishing the 
importance of role models for entrepreneurs is still scarce (Bosma et al., 2012, being an exception). Entrepreneurial role models have been found in particular in the family, and especially among parents (Greene, Han, and Marlow, 2013; Hoffman, Junge, and MalchowMøller, 2015; Lindquist, Sol, and van Praag, 2015). Only few studies have analyzed the determinants of the match between entrepreneurs and their role models (Gibson, 2004; Bosma et al., 2012). One of the recurrent findings is that being of the same gender increases the likelihood of the match (Lindquist, Sol, and van Praag, 2015) and this tends to be particularly relevant for females (Barnir, Watson, and Hutchins, 2011; Greene, Han, and Marlow, 2013; Hoffman, Junge, and Malchow-Møller, 2015). ${ }^{4}$

Role identification and social learning theories broadly define role models in the following way. Role models are cognitive constructions based on the attributes of persons in social roles, the individuals' perception to be similar to them to some extent, and the desire to increase perceived similarity through the emulation of those attributes and the achievement of similar goals (Shapiro, Haseltine, and Rowe, 1978; Gibson, 2004; Barnir, Watson, and Hutchins, 2011; Bosma et al., 2012; Obschonka et al., 2012; Greene, Han, and Marlow, 2013). Role models are, hence, viewed as references, as examples to be followed. Accordingly, they are expected to transfer or impute preferences (and even abilities) for certain occupations and/or lifestyles, through observation and social interaction (Hoffman, Junge, and Malchow-Møller,

\footnotetext{
${ }^{4}$ A related discussion concerns peer effects, with the transmission of entrepreneurial behavior from peers being documented in a variety of contexts, such as the workplace (Nanda and Sørensen, 2010), the university (Kacperczyk, 2013), and the neighborhood (Giannetti and Simonov, 2009). We briefly discussed this as an organizational feature that is likely to influence workers' entrepreneurship choices (Section 2.1).
} 
2015). Such observational learning is argued to be particularly effective within the same gender lines (McPherson, Lynn, and Cook, 2001; Gibson, 2004). ${ }^{5}$

Role models serve several interrelated functions. Besides providing learning, motivation and inspiration, support and guidance, they may also help individuals defining their self-concept and increase their self-efficacy, making people confident that they, too, can achieve a certain goal (Shapiro, Haseltine, and Rowe, 1978; Gibson, 2004; Barnir, Watson, and Hutchins, 2011). Entrepreneurial role models in particular may, thus, be a source for entrepreneurial learning and knowledge spillovers, legitimize entrepreneurial aspirations and actions, reduce uncertainty about the entrepreneurial process, and create several non-pecuniary benefits among role model users (Barnir, Watson, and Hutchins, 2011; Sørensen and Fassiotto, 2011; Bosma et al., 2012).

Behavioral differences between men and women that are related to entrepreneurship are, for instance, risk aversion (Charness and Gneezy, 2012), competitive attitudes (Gneezy and Rustichini, 2004), and entrepreneurial self-efficacy (i.e., one's belief regarding the ability to carry out tasks related to starting and running a new venture - e.g., Barnir, Watson, and Hutchins, 2011): Women's scores are lower, on average, than men's. The gender differences in these behavioral characteristics may partially explain why, in the absence of specific triggers or encouragement mechanisms, women may be less inclined to pursue a career in entrepreneurship, all else equal. The exposure to (same gender) entrepreneurial role models may therefore fulfill a much greater informational role for women and affect their behavior more strongly (Wilson, Kickul, and Marlino, 2007; Thébaud, 2010; Barnir, Watson, and Hutchins, 2011; Koellinger,

\footnotetext{
${ }^{5}$ Sociologists (Dryler, 1998; Barnir, Watson, and Hutchins, 2011) and economists (Linquist, Sol, and van Praag, 2015) even build tests of role modeling on the assumption that the correlation of the outcome measure between the individual and his or her role model should be higher for same gender matches.
} 
Minniti, and Schade, 2013; OECD, 2014). Female role models may, consequently, provide them the stimulus and access to resources that may not exist otherwise.

Besides these behavioral differences across genders (Koellinger, Minniti, and Schade, 2013), the historical lack of female entrepreneurs, and consequently the lack of female role models, probably also induced fewer women to become entrepreneurs today (Hoffman, Junge, and Malchow-Møller, 2015). The existence (and effectiveness) of (female) role models may attenuate gender-based perspectives, stereotypes and women's general disadvantages - for instance, in the search for credit (Thébaud, 2010). This paper contributes to this debate by evaluating to what extent entrepreneurial bosses may act as role models for the future entrepreneurship activities of their employees, and whether this may be particularly the case for female workers exposed to female entrepreneurs in the workplace.

\section{From Theory to Empirical Testing}

Our discussion, together with prior empirical evidence, indicates that female employees are less inclined to become entrepreneurs in the (near) future than male employees. This is a stylized fact. Both gender differences in behavioral traits, such as risk aversion and competitive attitudes (e.g., Koellinger, Minniti, and Schade, 2013), and stereotypes linking entrepreneurship to masculine traits (e.g., Thébaud, 2010) make female employees less likely than their male peers to leave wage employment towards entrepreneurship. From existing theories on entrepreneurial entry, we expect the (organizational) context to play an additional role on individuals' preferences for entrepreneurship, possibly mitigating the effects of those gender-differentiated perceptions. 
From the literature on Organizations as Fonts of Entrepreneurs discussed above, we already know that the interaction with colleagues with prior entrepreneurship experience shapes an individual's propensity to become an entrepreneur (Nanda and Sørensen, 2010). Recent research on female micro-entrepreneurs in low-income settings further suggests that sharing an entrepreneurial experience with a female peer catalyzes entrepreneurship among women and improves their success chances, owing to the encouragement, strengthened social network, and increased confidence obtained through friendship among women at work (Field et al., 2016).

As superiors, female leaders may, as well, be agents of change and transform social norms. From our previous discussion on Female Leaders and Gender Gaps inside Organizations, we find arguments supporting role modeling effects inside organizations, since similarity between employees and their superiors improves mentorship (Athey, Avery, and Zemsky, 2000; McPherson, Lynn, and Cook, 2001), and women who break traditional gender roles in the labor market are believed to encourage other lower-ranked women to invest in similar career paths (Cohen and Broschak, 2013; Smith, Smith, and Verner, 2013). Female entrepreneurs with close interaction with female employees may, hence, be able to provide them mentorship and demystify the entrepreneurial process (Barnir, Watson, and Hutchins, 2011).

This argument is further reinforced by recent research on Role Models in Entrepreneurship, which proposes that entrepreneurial role models (in the family) tend to be of the same gender (Lindiquist, Sol, and van Praag, 2015), and particularly relevant for women (Greene, Han, and Marlow, 2013; Hoffman, Junge, and Malchow-Møller, 2015).

By connecting these three lines of argument, we expect female entrepreneurial bosses to be a contextual factor inside organizations that is able to affect female employees' propensity to 
become entrepreneurs in the future, possibly by working as role models. We, therefore, develop our first hypothesis as follows:

Hypothesis 1 (H1): A female entrepreneurial boss affects the future entrepreneurship choice of female employees positively.

While we do not exclude the possibility that male entrepreneurial bosses also affect the future entrepreneurship choice of male employees positively - which would be, indeed, consistent with the idea that role models are often of the same gender of role model users (Bosma et al., 2012; Lindquist, Sol, and van Praag, 2015), and in general, share similar characteristics - the effect of working with an entrepreneurial boss of the same gender may be particularly relevant for women. First, those who are less exposed to entrepreneurship are likely to be more strongly affected by the interaction with others who had an entrepreneurial experience (Nanda and Sørensen, 2010; Obschonka et al., 2012), and women are less likely than men to report knowing an entrepreneur (Kelley et al., 2012). Second, male entrepreneurs are the "norm", while female entrepreneurs are the "exception", being therefore more likely to have an impact on existing social norms, changing gendered perceptions and motivating other women to follow similar career choices (Cohen and Huffman, 2007; Cohen and Broschak, 2013). Third, given the aforementioned gender differences in behavioral traits related to entrepreneurship (e.g., risk taking, self-efficacy), female entrepreneurial bosses may fulfill a much greater informational and motivational gap among female employees, than male entrepreneurial bosses do among male employees (Gibson, 2004; Barnir, Watson, and Hutchins, 2011). Therefore, our second hypothesis states that: 
Hypothesis 2 (H2): The positive effect of the exposure to an entrepreneurial boss of the same gender on employees' future entrepreneurship choices is stronger for female than for male employees.

The hypothesized mechanism for this result is that of role modeling. Female entrepreneurial bosses may serve as role models for the future entrepreneurship activities of lower-ranked female employees. This leads to our third hypothesis:

Hypothesis $3 \boldsymbol{a}(\mathbf{H} 3 \mathrm{a})$ : If female entrepreneurial bosses increase the propensity of female employees to become entrepreneurs in the future, this is because female entrepreneurial bosses act as role models.

We adopt two main tests for this hypothesis. First, we analyze how certain workplace characteristics (firm size and the gender composition of the workforce) moderate the effect that female entrepreneurial bosses exert on female employees' entrepreneurship choices. These factors may affect the extent to which female employees are exposed to and interact with a female entrepreneurial boss. Second, we test whether the similarity in other characteristics than gender (namely age and education background) reinforce the positive effect that female bosses have on lower-ranked women's entrepreneurship choices. The transmission of entrepreneurial knowledge and attitudes via role modeling is expected to be more effective in smaller organizations, with smaller shares of peers of the same gender (with whom, otherwise, an employee would have to share the boss' attention), and between bosses and employees with similar characteristics besides gender. 
As a final, indirect, test of the role model mechanism, we have to check the validity of an alternative mechanism advanced in our earlier discussion on Female Leaders and Gender Gaps inside Organizations: the "queen bee" mechanism. Female entrepreneurial bosses may act as "queen bees" in the organization, and this may drive female employees' decision to leave and choose entrepreneurship to escape from situations of wage discrimination, increased risk of displacement, or dissatisfaction with the current boss. We, thus, derive the alternative hypothesis:

Hypothesis $3 \boldsymbol{b}(\mathbf{H} 3 \boldsymbol{b})$ : If female entrepreneurial bosses increase the propensity of female employees to become entrepreneurs in the future, this is because female entrepreneurial bosses act as "queen bees".

In order to test the validity of this mechanism, we evaluate how employee-boss gender interactions affect these three labor outcomes at the employee-level: wages in the current workplace, the employee's probability of leaving to another firm, and the employee's probability of leaving wage employment and becoming unemployed.

\section{METHODS}

\section{Data Sources and Sample}

Our analysis is based on register data maintained by Statistics Denmark - the Integrated Database for Labor Market Research, referred to by its Danish acronym IDA. These data are attractive for this study for several reasons. First, it is comprehensive, covering everyone legally living in Denmark from 1980 until 2012, and providing detailed socio-economic data at the individual level. Individual information is collected every year, which makes the IDA dataset an 
annual census of the population residing in Denmark. Second, it covers a wide range of labor market phenomena, allowing to construct workers' career histories (including transitions between occupations, firms, and different bosses), which will be crucial to characterize individuals' experience in the labor market and their exposure to different (e.g., male and female, and also entrepreneurial) bosses. Finally, IDA is a longitudinal matched employer-employee dataset, which means that employees can be linked to their employers over time. This unique nature of the data allows us to study the role of bosses in possibly impacting employees' rates of entrepreneurship, using state-of-the-art econometric techniques to control for different sources of unobserved heterogeneity.

We construct our sample with three important factors in mind. First, we want to focus on brand new firms, i.e., newly founded workplaces without any connection to an existing company. ${ }^{6}$ This approach allows us to better identify entrepreneurial bosses, as we define below. Second, given that entrepreneurship is a relatively rare event on an annual basis, we want to study employees' likelihood of becoming an entrepreneur during multiple years. Using multiple years generates better power in our estimations, besides guaranteeing that our results are not driven by the specifics of one given year. Finally, we also want to use explanatory variables to characterize individual career histories using data prior to the time of entry into entrepreneurship.

Besides these sampling criteria, prerequisites to our analysis are unique and proper definitions of bosses and (workers' transitions into) entrepreneurship. Based on the classification of individuals' primary occupation, the boss is defined as the employer at the workplace. Since we focus on newly founded workplaces, which are mostly micro-sized, the founding business owner corresponds to the boss, allowing us to focus on entrepreneurial bosses, i.e., bosses who

\footnotetext{
${ }^{6}$ This means that new workplaces created through separation from an existing firm, the transfer of part of the workforce to a new plant in the same industry (e.g., spin-offs), or new firms resulting from mergers of existing plants are excluded from our sample.
} 
are entrepreneurs themselves. ${ }^{7}$ We exclude the cases when the boss is a family member of the worker (e.g., worker's father, mother, spouse/partner) to avoid confounding explanations of the role of the boss.

The identification of (workers' transitions into) entrepreneurship is also based on the classification of individuals' primary occupations. We start by using a broader entrepreneurship definition, which includes all those who transit into self-employment/independent work (with or without employees), employer categories, and those who are identified as founders of new businesses, according to Entrepreneurship Database files (also maintained by Statistics Denmark). A stricter definition will only consider those who become entrepreneurs and employ labor (i.e., those employing at least one wage earner at the year of entry into entrepreneurship), like the "bosses" in our sample. This narrower definition is closer to the theoretical concept of (Schumpeterian) entrepreneurship, which consists of potentially high ambition, growth-creating, innovative, and consequently higher-impact, entrepreneurs (Levine and Rubinstein, 2013; Henrekson and Sanadaji, 2014).

Given our sample criteria and key definitions, we cover all new workplaces founded between 2003 and 2007 where we can identify the entrepreneur-boss. ${ }^{8}$ All these workplaces employ at least one employee at the end of the entry year. Data prior to 2003 are used to describe workers' and bosses' history in the labor market. We then track all the workers hired at these newly founded workplaces since the year they join the firm to analyze their later career paths. We focus our analysis on full-time workers, i.e., a group that is expectedly homogeneous in their engagement level in the workplace and that is more likely to closely interact with - and, thus, be

\footnotetext{
${ }^{7}$ We made sure that the employer corresponds to the boss figure in the firm by checking a more detailed classification of his or her occupation, based on DISCO codes, which correspond to the Danish classification of the International Standard Classification of Occupations.

${ }^{8}$ This time window is further motivated by major changes in DISCO codes in 2003 and 2008.
} 
affected by - their boss. We follow them until they switch to entrepreneurship or until the last year of available information (right-censoring). This sample structure allows us to use discretetime event history models to study workers' transition into entrepreneurship.

Our final sample is composed of 13,931 newly founded workplaces with a known and unique employer (the boss). Twenty nice percent of these entrepreneurs $(4,036)$ are female. We identify a total of 162,138 workers hired at these workplaces over time, out of which 89,189 are hired as full-time workers, with no other primary occupation. ${ }^{9}$ A total of 1,966 full-time workers become entrepreneurs (i.e., self-employed or new business founders) after leaving the workplace, out of which $32 \%$ also employ labor in the year of transition (i.e., stricter - or "Schumpeterian" definition of entrepreneurship). The share of women among those becoming entrepreneurs varies between $29 \%$ and $31 \%$, according to the entrepreneurship definition used.

Descriptive statistics for the 89,189 full-time workers hired at those newly founded workplaces are shown in Table 1, separately for those becoming entrepreneurs in the future and those never switching to entrepreneurship during the period observed. We provide separate statistics for males and females in the Appendix (Table A.I). Table 1 also compares future entrepreneurs with those who leave the firm but not to entrepreneurship (e.g., movers to other firms).

On average, employees who become entrepreneurs are older and have higher education levels than their other peers employed at the workplace. These differences are especially evident among women (see Table A.I). Future entrepreneurs are more often married and had longer spells in unemployment in the past on average. All these differences are even more evident when we compare future entrepreneurs with other movers who chose different paths than

\footnotetext{
${ }^{9}$ Our main results are essentially unchanged when temporary and part-time workers are included in estimations.
} 
entrepreneurship. Apparently the difference between those who move out of an entrepreneurial firm and those who stay is not a "mover-stayer difference" (Elfenbein, Hamilton, and Zenger, 2010).

Workplaces spawning new entrepreneurs among employees tend to be smaller, in line with prior studies, although in this case we include only newly started entrepreneurial firms in our sample, both small and large (e.g., Dobrev and Barnett, 2005; Parker, 2009). While a strong presence of women in the workforce and female bosses seem to be negatively associated with the overall propensity to become an entrepreneur, the opposite pattern is observed when we look at women - female workers entering entrepreneurship had more often a female boss and a larger share of female peers in the workplace (see Table A.I). These patterns are partially explained by the different industry distribution of female and male bosses (see Table A.II in the Appendix). While the businesses run by female bosses are more often found in wholesale and retail trade, accommodation and food services, business services, and educational and healthcare services, a considerable share of male bosses are found in construction, the primary sector, and in transport and storage services. We acknowledge these differences in the industry distribution and (consequent) workforce composition of workplaces as potential determinants of workers' transition into entrepreneurship, and therefore we control for all these factors in our estimations.

$$
\text { *** Table } 1 \text { here } * * *
$$

\section{Empirical Issues and Methods}

An essential aspect of our empirical analysis involves accounting for a number of selectivity issues driven by unobserved attributes of both bosses and workers, which may bias our results if neglected. Bosses and workers are, of course, heterogeneous with respect to a number of aspects we cannot observe, such as their innate ability or quality, entrepreneurial talent or preferences for 
certain work environments. These unobserved traits (which we refer to as unobserved heterogeneity) are likely to (partly) drive their mobility decisions. Bosses may select (or leave) employees, and employees may select (or leave) bosses. This switching may be non-random but driven by both boss and employees' characteristics that are partly unobserved to us, such as their quality (e.g., Lazear, Shaw, and Stanton, 2015)). These issues imply that workers and bosses are not randomly assigned to each other (see also Giuliano, Levine, and Leonard, 2011; Kunze and Miller, 2014). Instead, there is a potential assortative matching (partly) based on their unobserved attributes, which means that employees' and boss' unobserved quality are correlated. This also means that the worker-boss match is likely to be endogenous.

We address these issues using recently developed multi-level mixed-effects models (Abowd, Kramarz, and Woodcock, 2008; Rabe-Hesketh and Skrondal, 2012; Woodcook, 2015), which combine features of both fixed and random effect estimators. Similar to Lazear, Shaw, and Stanton's (2015) methods to study boss effects on worker's productivity, this method addresses the possible unobserved sorting effects mentioned above by allowing heterogeneous workers (e.g., in their unobserved quality) to be grouped with heterogeneous bosses. The great advantage of this method is that it allows for the effect of a boss to vary from worker to worker, depending on the quality of their match, besides taking into account workers' and bosses' unobserved traits. Thus, the most likely source of non-random sorting - i.e., through assignment based on workerboss match quality - is also captured in this model.

Given the structure of the dataset, basically based on an annual "snapshot" of all individuals and firms of interest in the database at a fixed point in time, we estimate multi-level mixed effects models for discrete time duration data to study the entrepreneurial entry decision of full-time workers employed in newly founded workplaces. The probability of each worker $i$, 
with boss $b$, leaving the workplace to enter entrepreneurship in the year $t+1$, will be modeled as a function of worker's gender, worker-boss gender similarity, and the interaction between the two, always controlling for several worker and boss characteristics (see Table 1), year, region, and industry fixed effects. Formally, the baseline three-level mixed model for the worker's probability of transiting into entrepreneurship in $t+1$ can be written as follows ${ }^{10}$ :

$$
\operatorname{Pr}\left(E_{i b t+1}=1\right)=H\left(\beta_{1} F_{i}+\beta_{2} F_{b}+\beta_{3} F_{i} \cdot F_{b}+\boldsymbol{X}_{i t} \boldsymbol{\alpha}+\boldsymbol{Z}_{b t} \boldsymbol{\delta}+\tau_{t}+\gamma_{y}+\mu_{j}+\lambda_{r}+\zeta_{i b}^{(2)}+\zeta_{b}^{(3)}+\varepsilon_{i b t}\right)
$$

where $F_{i}$ and $F_{b}$ are female dummies for each worker and boss; $\boldsymbol{X}_{i t}$ and $\boldsymbol{Z}_{b t}$ are a set of worker and boss characteristics; $\tau_{t}$ denote duration (i.e., worker's tenure) dummies; $\gamma_{y}, \mu_{j}$, and $\lambda_{r}$ are year, industry (2-digit), and region fixed effects; $\zeta_{i b}^{(2)}$ and $\zeta_{b}^{(3)}$ are the worker-level and boss-level random effects, with zero mean and variances $\psi^{(2)}$ and $\psi^{(3)}$, respectively; $\varepsilon_{i b t}$ is the level 1-error term; and $H(\cdot)$ is the inverse of the complementarity log-logistic function. The error terms are assumed to be uncorrelated across levels, so their variances add up to the total variance, allowing us to further estimate the relative contribution of boss-heterogeneity for the variance in workers' entrepreneurship rates.

As a robustness check, we extend this baseline specification using alternative definitions for entrepreneurship and for the exposure to bosses of the same gender. To further test the consistency of our results and the validity of our econometric method to capture some likely biases causes by endogenous worker-boss sorting, we also re-estimate this baseline specification in several sub-samples where the selectivity issues previously described are less likely to be an issue. First, we excluded those few cases where the founder was replaced by another boss later

\footnotetext{
${ }^{10}$ The subscripts for time are removed from the right-hand side of the equation for simplicity.
} 
on during the period observed, in order to eliminate the concerns about non-random boss switching. We also repeat the analysis for employees hired after having been displaced from a previous firm due to closure or massive downsizing. These individuals are more likely to have faced an exogenous shock that forced them to move towards another firm (and boss). They are therefore expected to select the new boss more randomly. Finally, we restrict the estimation to the very first hires of those newly founded businesses. Given that they have less information about the quality of the firm and of the boss as an entrepreneur, they are also believed to be less driven by factors that we cannot observe.

\section{RESULTS}

\section{The role of same gender entrepreneurial bosses in spawning entrepreneurship among workers}

We start by estimating our baseline equation (1) for all the full-time workers hired at newly founded workplaces with a known boss since 2003. The first two columns of Table 2 summarize the key results of interest to test the validity of our Hypothesis 1: whether or not female entrepreneurial bosses affect positively female employees' future entrepreneurship choices.

*** Table 2 here $* * *$

Whatever entrepreneurship definition we use, the results confirm that women are significantly less likely to leave the workplace to become an entrepreneur than men, even after controlling for several characteristics and labor market experiences that may be different for men and women (recall Table A.I). This confirms our assumption that gender gaps in entrepreneurship propensity remain large and significant even when employees work in more pro-entrepreneurial firms, i.e., smaller firms, where they are in more direct contact with an 
entrepreneur, and where they may perform a wide variety of tasks that also endow them with a broader set of skills. However, the exposure of female workers to a female boss is found to increase their propensity to enter entrepreneurship afterwards. This result gives support to our first hypothesis and indicates that female entrepreneurial bosses may help reducing the differential in entrepreneurship entry rates between men and women.

Next we extend this specification to test whether the same result is found for male workers exposed to male bosses. We replace the Female Boss dummy by an indicator variable for same gender matches between the employee and the boss. The last two columns of Table 2 summarize the results and show that having an entrepreneurial boss of the same gender is only significantly associated with future entrepreneurship choices of women. In other words, men are more likely to become entrepreneurs than women, regardless the gender of their boss. Women, instead, seem to be affected by the exposure to a female boss. This result is robust against using alternative definitions of exposure to a boss of the same gender. ${ }^{11} \mathrm{We}$, thus, find consistent support for the hypothesis that the positive effect of the exposure to an entrepreneurial boss of the same gender on employees' future entrepreneurship choices is stronger for female than for male employees (Hypothesis 2). The mechanism behind this effect is still unknown, and will be further explored in later sections. All in all, the results indicate that the role of the boss is nonnegligible. According to the estimates shown in Table 2 for the broader entrepreneurship definition, $19 \%$ of the variance in workers' entrepreneurship rates is attributed to differences between their bosses (around 13\% in case we use a stricter entrepreneurship definition). This

\footnotetext{
${ }^{11}$ In alternative specifications, we replaced the Same Gender Boss dummy by a time-varying variable measuring the cumulative exposure to a boss of the same gender within the workplace (i.e., share of worker's tenure - in years with a boss of the same gender). The results remain qualitatively similar, also after controlling for the gender of previous bosses from previous jobs. The worker-boss interactions in the current workplace are found to be more significantly related to workers' transitions into entrepreneurship afterwards.
} 
particular contextual factor - one's boss - has indeed a considerable influence on employee's future choices for entrepreneurship.

The results obtained for other variables (not reported) are in line with prior evidence found in the literature. The likelihood of entering entrepreneurship increases with a worker's age (at a decreasing rate), education, and is higher for married people (e.g., Koellinger, Minniti, and Schade, 2013). Workers with a more diversified labor experience (in terms of number of different workplaces where they were employed before) are also more likely to become entrepreneurs (see also Rocha, Carneiro, and Varum, 2015). This is consistent with Lazear's Jack-of-All-Trades hypothesis (Lazear, 2005). Longer spells in unemployment prior to the current job, on the other hand, seem to decrease the likelihood of leaving wage employment to become an entrepreneur, consistent with higher opportunity cost of leaving the current job for entrepreneurship for those workers who experienced longer unemployment periods in the past. ${ }^{12}$

At the workplace-level, size seems to be the most relevant factor influencing workers' decision to leave towards entrepreneurship. Similar to prior studies (Sørensen, 2007; Parker, 2009), our results indicate that workers' entrepreneurial propensity is negatively related to the size of the workplace. Though workers may self-select into workplaces of different sizes with the intention of learning from small business owners and becoming entrepreneurs in the future, the fact that our methods control for workers' unobserved traits (which may include permanent preferences for entrepreneurship) mitigates the potential bias in our main results of interest caused by this selectivity issue. Last but not least, regarding boss' characteristics, we find the workers' entrepreneurship rates to be inversely related with boss' age.

\footnotetext{
${ }^{12}$ See, for instance, Fairlie (2013) for a comparable discussion on the opportunity costs of leaving wage employment towards entrepreneurship during recessions.
} 


\section{Sensitivity Analysis: Alternative Sub-samples and Peer Effects}

Our estimation method controls for the fact that heterogeneous employees (e.g., in quality) are grouped with different bosses and, thus, for the match quality between each worker and her respective boss (which is unobserved). Nevertheless, we run sensitivity analyses for the potential selectivity problems previously discussed. By repeating our baseline estimations in sub-samples where non-random assignment of workers to bosses is less likely to be a problem, we test the validity of our method in tackling these issues.

First, we exclude the rare cases of firms where the founder has been replaced by another boss over the period observed. The results from the estimation of multi-level mixed models for employees' entrepreneurship choices are summarized in the first column of Table 3 . The conclusions derived from previous estimations remain qualitatively unchanged, indicating that non-random mobility of bosses between workforces (e.g., when lower/higher quality bosses tend to move from/to lower/higher quality workforces) is indeed not biasing our main results.

We next re-estimate our main equation for subsamples of workers who are less likely to self-select into workplaces/bosses based on their unobserved preferences for some (un)observed characteristics of workplaces/bosses. First, we restrict the analysis to those workers who were displaced from firms that either closed or suffered a massive downsizing before joining the workplaces under study (second column). ${ }^{13}$ Whereas job loss is likely to be quite exogenous for these workers, they are believed to be more restricted in their choice set than workers voluntarily leaving prior firms/bosses and moving to other firms/bosses. They are, therefore, more likely to accept a new job/boss more randomly, being potentially less influenced by their preferences for certain characteristics of the hiring bosses. Furthermore, these employees are likely to have

\footnotetext{
${ }^{13}$ Massive downsizing at the workplace-level is defined by a reduction in the workforce between two consecutive years larger or equal to $30 \%$, with a minimum of five displaced workers.
} 
witnessed a bad entrepreneurial experience by their previous employer. Therefore, they may be less likely to become entrepreneurs themselves. Secondly, we look at the very first workers hired by these newly founded workplaces in the year of start-up (third column). Self-selection of workers into certain bosses/workplaces is less likely to be an issue among the first hires, who have less information about the quality of the business, the workforce, or the boss herself as an entrepreneur, which could bias their decision of joining the workplace. For both groups of workers, we still find that female entrepreneurial bosses increase the propensity of their female employees to enter entrepreneurship afterwards. Our main results seem not to be biased by selectivity problems.

Finally, we confirm the robustness of our results when controlling for peer effects at the firm-level (last column of Table 3, coefficient of peer effects not tabulated). If the most entrepreneurial bosses are more likely to be matched with more entrepreneurial workforces, or if workers self-select into teams with more entrepreneurial peers, peer effects could actually confound the estimates. The only way in which we can identify entrepreneurial colleagues is based on their previous entrepreneurial experience. The share of coworkers with previous entrepreneurial experience is quite low though (on average, only $5.5 \%$ of the peers in the workplace were entrepreneurs in the past ${ }^{14}$. The results confirm that boss effects remain significant and in line with our previous conclusions.

*** Table 3 here $* * *$

\footnotetext{
${ }^{14}$ We use the broad definition of entrepreneurship (i.e., including periods in self-employment) when considering previous entrepreneurship experience of peers.
} 


\section{UNDERLYING MECHANISMS}

\section{Are Female Bosses Entrepreneurial Role Models?}

We consistently demonstrated that a female entrepreneurial boss affects the future entrepreneurship choices of female employees positively (Hypothesis 1), and that the positive effect of being exposed to an entrepreneurial boss of the same gender is especially strong for female employees (Hypothesis 2). As hypothesized earlier, the mechanism explaining this result may be the fact that female entrepreneurial bosses act as role models among their female employees (Hypothesis 3a). We now test the validity of the role modeling hypothesis.

First, we investigate the role modeling mechanism by allowing the effect of female entrepreneurial bosses to vary according to two characteristics of the workforce - its size and the relative presence of female peers. From our prior estimations, we already know that employees' propensity to enter entrepreneurship afterwards is inversely related to the size of the previous workplace. By extending those baseline equations, we now verify that this result is even stronger for female workers employed by female bosses (two first columns of Table 4). The smaller the workplace, the closer the interaction with the entrepreneurial boss, which may better promote the transmission of entrepreneurial knowledge from the boss to the worker. Our results suggest that this mechanism is indeed stronger among women. The results are robust to different definitions of entrepreneurship.

*** Table 4 here ***

We find further support for the role modeling hypothesis by analyzing how differently female workers are affected by female entrepreneurial bosses according to the gender composition of the workforce (last two columns of Table 4). Female bosses play an even stronger role for female workers' entrepreneurship decisions when the share of female workers 
in the workforce is smaller. On the one hand, female employees may be more motivated by female bosses leading male-dominated workforces, whom they may view as stronger female leaders. On the other hand, the transmission of entrepreneurship knowledge, intention, and skills may be stronger when the employee does not have to share the boss' attention with same gender peers. ${ }^{15}$ The results (not reported) remain consistent when we use alternative measures for the exposure to same gender bosses (e.g., share of employee's tenure with a boss of the same gender).

As discussed earlier, role model identification theory suggests that role models are not only of the same gender, but likely to be identical in other dimensions as well (Gibson, 2004), and their mentoring and learning functions might be more effective when they exhibit a high degree of resemblance with role model users (Bosma et al., 2012; Lindquist, Sol, and van Praag, 2015). Agents tend to associate disproportionately with those having similar traits, which usually include (besides gender) age, race, profession, and education levels. This is often referred to as the homophily principle in social networks (McPherson, Lynn, and Cook, 2001; Golub and Jackson, 2012).

Therefore, as an additional test of the role modeling hypothesis, we investigate how worker-boss homophily (i.e., similarity) in other characteristics than gender are associated with workers' propensity to become entrepreneurs afterwards, and how these similarities moderate or reinforce the role played by female bosses on female workers. Role modeling effects tend to get stronger as more types of similarities exist between two individuals (McPherson, Lynn, and Cook, 2011). We look at two particular aspects - age and educational background (both the level

\footnotetext{
${ }^{15}$ See, for instance, Lindquist, Sol, and van Praag (2015), who also find stronger effects for same-sex parent-child transmission of entrepreneurship, though the effect diminishes with the number of same-sex siblings.
} 
and the field of education). ${ }^{16}$ These two dimensions of homophily are often referred to be important in the context of entrepreneurial teams and networks (Ruef, Aldrich, and Carter, 2003; Forbes et al., 2006). The results are summarized in Table 5.

We find that the worker-boss similarity in both dimensions reinforces the positive effect of same gender bosses among women. The transmission of entrepreneurial behavior seems to be more likely when workers and bosses are similar in several characteristics. These results give further support to the idea that female entrepreneurial bosses act as role models among their female employees, as hypothesized in our Hypothesis $3 \mathrm{a}^{17}$

*** Table 5 here $* * *$

\section{Are Female Bosses "Queen Bees"?}

An alternative mechanism - outside of our theory, but frequently advanced by studies on the effect of female leaders on gender gaps inside organizations (e.g., Bagues and Esteves-Volart, 2010; Maume, 2011) - is the so-called "queen bee syndrome". As hypothesized earlier (Hypothesis 3b), female entrepreneurial bosses could be acting as "queen bees" and, consequently, push their female employees into alternative career paths, such as

\footnotetext{
${ }^{16}$ We consider that the boss and the employee have similar age ranks when their absolute age difference is not higher than five years. Regarding education, we have detailed information on individual's highest education attained annually, based on 8-digit education classification. We use the first four digits to compare worker's and boss' education: the first two digits describe the level of education (e.g., secondary, vocational, bachelor, etc.), while the next two digits provide information about the broad educational field (e.g., industry specialization in the case of vocational education, or the academic field in the case of tertiary education).

${ }^{17}$ As a final robustness check, we also controlled for entrepreneurship among workers' parents and spouses, i.e., whether any of them are self-employed or a business owner, with or without employees. Including these control variables in our estimations significantly reduces the number of observations, because it is not always possible to identify the worker's mother, father and spouse (only possible for married or cohabiting couples) in the data. Considering both the father's and mother's occupation reduces the total number of worker*year observations by $40 \%$. The number of observations is further reduced if we additionally take into account the occupation of the spouse. Even so, the results remain qualitatively similar after we control for the existence of entrepreneurs in the workers' close relatives, which offer additional robustness to the role modeling effect of female entrepreneurial bosses.
} 
entrepreneurship. Given that we are analyzing newly founded small ventures where the entrepreneurial boss is also the employer, we believe that this "queen bee" syndrome may be less relevant than it would be in larger organizations, where female leaders may not have a direct role in recruitment. Even so, we check the validity of this alternative mechanism, and test whether female employees with female entrepreneurial bosses end up in more disadvantaged positions in the labor market than female employees with a male boss. We do this by analyzing whether female entrepreneurial bosses affect female and male employees' outcomes differently.

We look at the employees' probability of leaving the current workplace towards another job in a different firm, their risk of leaving towards unemployment, and their hourly wage in the current firm. If female bosses act as "queen bees" inside organizations, we expect female workers to be penalized relative to their male counterparts (i.e., female bosses will have a negative effect on their outcomes) and to be more dissatisfied with their current boss if exposed to female bosses. This may result in an increased probability of leaving the current employer towards another one (in a different firm). An increased risk of displacement and augmented wage gaps compared to male workers in female-led firms are two other sources of evidence that can indicate that female bosses are acting as "queen-bees" and possibly pushing female workers into entrepreneurship.

Table 6 summarizes the key results from the estimation of for the three aforementioned outcomes. We analyze whether the exposure to a female entrepreneurial boss affects any of those outcomes, and whether this effect differs for female and male employees. Again, we employ 
multi-level mixed models for all three outcomes, such that the effects we measured will not be biased due to selectivity issues. ${ }^{18}$

$* * *$ Table 6 here $* * *$

The results suggest that female employees earn significantly lower wages and have a higher probability of moving to another job, after controlling for several individual, workplace, and boss characteristics (including the unobserved quality of the employee-boss match). The exposure to a female entrepreneurial boss is found to increase the probability of leaving the firm, either towards another firm or towards unemployment. Female entrepreneurial bosses also pay lower wages than their male counterparts. However, the results indicate that female employees are relatively more protected when they work for a female entrepreneur, rather than a male entrepreneur: they have a lower propensity to leave to another job (which may indicate they are more satisfied with the current boss match when the boss is a woman), they are less exposed to the risk of becoming unemployed afterwards, and the negative wage differential relative to male employees is narrower when there is a female boss in the firm.

Overall, the results do not provide any evidence of female bosses favoring men over women in the workplace, and so acting as "queen bees". Instead, female bosses may actually help narrowing gender wage gaps (see, for instance, Cohen and Huffman (2007) and Cardoso and Winter-Ebmer (2010), who also found that the impact of a female boss on wages may be detrimental among male employees). As a result, we exclude the possibility that the mechanism explaining the greater entrepreneurial propensity of female workers with female bosses is a "queen bee" effect (Hypothesis 3b), according to which female bosses would be hindering or penalizing the career progress of lower-ranked women, potentially pushing them to search for

\footnotetext{
${ }^{18}$ Alternative estimations of multinomial logit regressions modeling the several paths of the worker (transition to i) another job, ii) unemployment, or iii) entrepreneurship) and using "stayers with the current boss" as a reference category provide similar results.
} 
better outside opportunities. These results also offer further robustness to our main hypothesis that female entrepreneurial bosses act as role models for their female employees (H3a).

\section{DISCUSSION AND CONCLUSIONS}

Uncovering key determinants of entrepreneurial behavior can help entrepreneurial educators, consultants, advisors, and policy makers to find the right way to foster (promising) entrepreneurship. Entrepreneurial role models are viewed as a possible source of relevant human and social capital. A better understanding of this potential driver of entrepreneurship may lead to the development and use of additional (policy) instruments to enhance entrepreneurial activity and outcomes, especially among individuals who may be less inclined to engage in entrepreneurial activities, but not necessarily less able to perform well as entrepreneurs, such as women (OECD, 2014).

\section{Theoretical and Empirical Contributions}

Our main contribution is a (first) study of the impact of (entrepreneurial) bosses on future entrepreneurship choices of their current employees, and the mechanisms underlying this effect. Using rich register data for Denmark, and empirical methods that take into account the unobserved quality of the match between each employee and her boss, we build on existing entrepreneurship theories and address the long-lasting debates between contextual and dispositional approaches of entrepreneurial entry. We investigate the role of a particular contextual factor in (differentially) stimulating male and female employees to become entrepreneurs: the exposure to (female versus male) entrepreneurial bosses inside organizations. 
Our findings represent a significant contribution to existing theories and to recent empirical evidence regarding social transmission of behaviors and attitudes across individuals in the context of entrepreneurship. We contribute in particular to previous theories of gender inequality in entrepreneurship entry, by theorizing and empirically validating that the organizational context where employees are inserted, namely the interaction with bosses of the same gender who are entrepreneurs themselves, may mitigate the effect of dispositional factors. Given the wide set of controls considered in our empirical analysis, we are confident that the gender gaps identified in our results capture the effect of gender differences in dispositional factors, such as risk taking preferences, ability, competitive attitudes, and entrepreneurial selfefficacy.

More broadly, our study also contributes to the growing debate and literature on gender diversity in company boards (e.g., Foss and Lyngsie, 2016). In this debate, a common justification for the desirability of gender diversity in top management teams is the spillover effect of female board members to future female board members (e.g., Ahern and Dittmar, 2012; Dezsö and Ross, 2012) and women in lower ranks (e.g., Bagues and Esteve-Volart, 2010; Cardoso and Winter-Ebmer, 2010). While most of these studies have been looking at large companies, evidence on newly founded, smaller, companies where workers tend to be differently exposed to their boss, is still rare. By studying new workplaces where bosses are entrepreneurs, hierarchies are flatter, and worker-boss interactions are closer, we are able to obtain clearer effects of the exposure to same gender (entrepreneurial) bosses on workers' (entrepreneurship) outcomes. 


\section{Implications for Practice and Policy}

Our study has important practical implications. Our findings indicate that entrepreneurial role models may provide a different functionality for men and women. Role models may be especially relevant for women, offering them relatively more training, advice, motivation, and instructional support related to entrepreneurship activities, as women lack them to a higher extent compared to men. Furthermore, given the changing roles and stereotypes of women, it is also possible that women are more open to input from role models than men.

This paper also adds new insights to the increasing public discussion on the extent to which role models can be a policy instrument. The historical lack of female entrepreneurs, and consequently the lack of female role models, may thus be part of the reason for the fewer women among entrepreneurs today. Changing this pattern requires a concerted political effort building on attentive ways of providing female entrepreneurial role models. Role models may change perceptions of self-efficacy and set meaningful examples, so publicizing (female) entrepreneurial successes that are credible role models may increase individuals' (and particularly women's) perceptions that starting a business is indeed feasible, and make vicarious learning possible.

\section{Limitations and Future Research}

Studying newly founded workplaces, mostly micro- or small-sized, provides a pertinent setting to investigate the effect of entrepreneurial bosses on employees' future entrepreneurship choices, by making sure that employees are more directly exposed to their boss than in large, existing, corporations. This empirical setting also allows us identifying entrepreneurial bosses in a clearer way than using larger and more mature ventures. However, we acknowledge that (female) employees joining these firms may be different from other (female) employees joining larger 
established companies. This issue is, however, mitigated by the fact that we do not look only at early hires, but also at employees joining the workplace in later stages of the firm lifecycle. Even so, we strongly encourage future research to investigate these questions in other settings, in order to corroborate and reinforce the external validity of our study.

Another question that directly arises from our study is whether the exposure to entrepreneurial role models at the workplace also relates to future entrepreneurial performance of those who finally engage in entrepreneurship, or is affected by the performance of the entrepreneurial role models themselves. Future research might study the effect of (the performance of) entrepreneurial role models on the venture performance of role model users. Moreover, future research might address the learning aspects of the entrepreneurial bossemployee interaction, and which factors (dispositional and contextual) improve the chances of learning from previous entrepreneurial bosses.

\section{Conclusion}

This study shows that entrepreneurial bosses explain a relevant share of the total variance in workers' entrepreneurship rates. Working for an entrepreneurial boss of the same gender increases individuals' probability of entering entrepreneurship afterwards, especially among women. Our results do not provide any evidence that female bosses act as "queen bees" at the workplace, which could push female workers into entrepreneurship due to gender discrimination within the workplace. Our analysis, instead, finds consistent support for the role modeling hypothesis, according to which female entrepreneurial bosses act as role models for the entrepreneurship activities of their female employees, contributing to narrowing the gender gaps in workers' propensity to engage in entrepreneurship. 


\section{REFERENCES}

Abowd, J. M., F. Kramarz, and S. Woodcock

2008 "Econometric analyses of linked employer-employee data.” In L. Mátyás and P. Sevestre (eds.), The Econometrics of Panel Data, 22: 727-760. Berlin: Springer.

Ahern, K. R., and A. K. Dittmar

2012 "The changing of the boards: The impact on firm valuation of mandated female board representation.” The Quarterly Journal of Economics, 127(1): 137-197.

Alesina, A., and E. La Ferrara

2005 "Ethnic diversity and economic performance." Journal of Economic Literature, 43(3): $762-800$.

Athey, S., C. Avery, and P. Zemsky

2000 “Mentoring and diversity." American Economic Review, 90(4): 765-786.

Bagues, M. F., and B. Esteve-Volart

2010 "Can gender parity break the glass ceiling? Evidence from a repeated randomized experiment." Review of Economic Studies, 77(4): 1301-1328.

Barnir, A., W. E., Watson, and H. M. Hutchins

2011 "Mediation and moderated mediation in the relationship among role models, selfefficacy, entrepreneurial career intention, and gender." Journal of Applied Social Psychology, 41(2): 270-297.

Bednar, S., and D. Gicheva, D.

2014 “Are female supervisors more female friendly?" American Economic Review, 104(5): $370-375$.

Bhide, A.

1994 "How entrepreneurs craft strategies that work?" Harvard Business Review, 72(2): 150161. 
Blau, F. D., and J. Devaro, J.

2007 "New evidence on gender differences in promotion rates: An empirical analysis of a sample of new hires.” Industrial Relations, 46(3): 511-550.

Bosma, N., J. Hessels, V. Schutjens, M. van Praag, and I. Verheul

2012 “Entrepreneurship and role models.” Journal of Economic Psychology, 33(2): 410-424.

Burton, M. D., J. B. Sørensen, and C. M. Beckman

2002 "Coming from good stock: career histories and new venture formation." In M. Lounsbury and M. J. Ventresca (eds.), Research in the Sociology of Organizations, 19: 229-262. New York: Elsevier Science.

Buttner, E. H., and D. P. Moore

1997 “Women's organizational exodus to entrepreneurship: self-reported motivations and correlates with success.” Journal of Small Business Management, 35(1): 34-46.

Cardoso, A. R., and R. Winter-Ebmer

2010 "Female-led firms and gender wage policies." Industrial and Labor Relations Review, 64(1): 143-163.

Charness, G., and U. Gneezy

2012 "Strong evidence for gender differences in risk taking." Journal of Economic Behavior \& Organization, 83(1): 50-58.

Cohen, L. E., and J. P. Broschak

2013 "Whose jobs are these? The impact of the proportion of female managers on the number of new management jobs filled by women versus men.” Administrative Science Quarterly, 58(4): 509-541.

Cohen, P. N., and M. L. Huffman

2007 "Working for the women? Female managers and the gender wage gap." American Sociological Review, 72(5): 681-704. 
Dahl, M. S., C. L., Dezsö, and D. G. Ross

2012 "Fatherhood and managerial style: How a male CEO's children affect the wages of his employees.” Administrative Science Quarterly, 57(4): 669-693.

Dezsö, C. L., and D. G. Ross

2012 "Does female representation in top management improve firm performance? A panel data investigation.” Strategic Management Journal, 33(9): 1072-1089.

Dobrev, S. D., and W. P Barnett

2005 "Organizational roles and transition to entrepreneurship." Academy of Management Journal, 48(3): 433-449.

Dryler, $\mathrm{H}$.

1998 "Parental role models, gender, and educational choice." The British Journal of Sociology, 49(3): 375-398.

Elfenbein, D. W., B. H. Hamilton, and T. R. Zenger

2010 "The small firm effect and the entrepreneurial spawning of scientists and engineers." Management Science, 56(4): 659-681.

Field, E., S. Jayachandran, R. Pande, and N. Rigol

2016 "Friendship at work: Can peer effects catalyze female entrepreneurship?" American Economic Journal: Economic Policy, 8(2): 125-153.

Forbes, D. P., P. S. Borchert, M. E. Zellmer-Bruhn, and H. J. Sapienza

2006 "Entrepreneurial team formation: An exploration of new member addition", Entrepreneurship Theory \& Practice, 30(2), 225-248.

Foss, N., and J. Lyngsie

2016 "The more, the merrier? Women in top management teams and entrepreneurship in established firms." Strategic Management Journal, DOI: 10.1002/smj.2510.

Giannetti, M., and A. Simonov

2009 "Social interactions and entrepreneurial activity." Journal of Economics \& Management Strategy, 18(3): 665-709. 
Gibson, D. E.

2004 "Role models in career development: New directions for theory and research." Journal of Vocational Behaviour, 65(1): 134-156.

Giuliano, L., D. I. Levine, and J. Leonard

2011 "Racial bias in the manager-employee relationship. An analysis of quits, dismissals, and promotions at a large retail firm.” The Journal of Human Resources, 46(1): 26-52.

Gneezy, U., and A. Rustichini

2004 “Gender and competition at a young age." American Economic Review, 94(2): 377-381.

Goldin, C.

2014 "A grand gender convergence: Its last chapter." American Economic Review, 104(4): 1091-1119.

Golub, B., and M. O. Jackson

2012 "How homophily affects the speed of learning and best-response dynamics." The Quarterly Journal of Economics, 127(3): 1287-1338.

Gompers, P., J. Lerner, J., and D. Scharfstein

2005 "Entrepreneurial spawning: Public corporations and the genesis of new ventures, 1986 to 1999." The Journal of Finance, 60(2): 577-614.

Goodall, A. H., L. M. Kahn, and A. J. Oswald

2011 "Why do leaders matter? A study of expert knowledge in a superstar setting." Journal of Economic Behavior \& Organization, 77(3): 265-284.

Greene, F. J., L. Han, L., and S. Marlow

2013 'Like mother, like daughter? Analyzing maternal influences upon women's entrepreneurial propensity." Entrepreneurship Theory \& Practice, 37(4): 687-711.

Henrekson, M., and T. Sanandaji

2014 "Small business activity does not measure entrepreneurship." Proceedings of the National Academy of Sciences of the United States of America, 111(5): 1760-1765. 
Hensvik, L. E.

2014 "Manager impartiality: Worker-firm matching and the gender wage gap." Industrial \& Labor Relations Review, 67(2): 395-421.

Hoffmann, A., M. Junge, and N. Malchow-Møller

2015 "Running in the family: parental role models in entrepreneurship." Small Business Economics, 44(1): 79-104.

Hughes, K. D.

2003 "Pushed or pulled? Women's entry into self-employment and small business ownership." Gender, Work, and Organization, 10(4): 432-454.

Hyytinen, A., and M. Maliranta

2008 "When do employees leave their job for entrepreneurship?" Scandinavian Journal of Economics, 110(1): 1-21.

Kacperczyk, A.

2013 "Social influence and entrepreneurship: The effect of university peers on entrepreneurial entry." Organizational Science, 24(3): 1-20.

Kacperczyk, A.

2012 "Opportunity structures in established firms: Entrepreneurship versus Intrapreneurship in mutual funds.” Administrative Science Quarterly, 57(3): 484-521.

Kelley, D. J., A. Ali, C. Brush, A. C. Corbett, M. Majbouri, and E. G. Rogoff

2012 Global Entrepreneurship Monitor (GEM) 2012. United States Report, GEM Consortium.

Krueger, N. F., and D. Brazeal

1994 "Entrepreneurial potential and potential entrepreneurs." Entrepreneurship Theory \& Practice, 18(3): 91-104.

Koellinger, P., M. Minniti, and C. Schade

2013 "Gender differences in entrepreneurial propensity." Oxford Bulletin of Economics and Statistics, 75(2): 214-234. 
Kunze, A., and A. R. Miller

2014 "Women helping women? Evidence from private sector data on workplace hierarchies." NBER Working Paper no. 20761.

Lazear, E.

2005 “Entrepreneurship.” Journal of Labor Economics, 23(4): 649-680.

Lazear, E. P., K. L. Shaw, and C. T. Stanton

2015 “The value of bosses.” Journal of Labor Economics, 33(4): 823-861.

Lazear, E., and M. Gibbs

2015 Personnel Economics in Practice. $3^{\text {rd }}$ Edition: Wiley.

Lazear, E., and S. Rosen

1990 “Male-female wage differences in job ladders.” Journal of Labor Economics, 8(1/2): 106123.

Levine, R., and Y. Rubinstein

2013 "Smart and illicit: Who becomes an entrepreneur and do they earn more?" NBER Working Paper No. 19276.

Lindquist, M., J. Sol, and M. van Praag

2015 "Why do entrepreneurial parents have entrepreneurial children?" Journal of Labor Economics, 33(2): 269-296.

Lyness, K. S., and M. E. Heilman

2006 "When fit is fundamental: Performance evaluations and promotions of upper-level female and male managers.” Journal of Applied Psychology, 91(4): 777-785.

Matsa, D. A., and A. R. Miller

2011 "Chipping away at the glass ceiling: Gender spillovers in corporate leadership." American Economic Review, 101(3): 635-649. 
Maume, D. J.

2011 "Meet the new boss... same as the old boss? Female supervisors and subordinate career prospects." Social Science Research, 40(2): 287-298.

McPherson, M., S. Lynn, and J. M. Cook

2001 "Birds of a Feather: Homophily in Social Networks." Annual Review of Sociology, 27: 415-444.

Nanda, R., and J. B. Sørensen

2010 “Workplace peers and entrepreneurship.” Management Science, 56(7): 1116-1126.

Obschonka, M., M. Goethner, R. K. Silbereisen, and U. Cantner

2012 "Social identity and the transition to entrepreneurship: The role of group identification with workplace peers.” Journal of Vocational Behaviour, 80(1): 137-147.

\section{OECD}

2014 Enhancing women's economic empowerment through entrepreneurship and business leadership in OECD countries. Final report, OECD Directorate for Employment, Labour and Social Affairs.

Parker, S. C.

2009 "Why do small firms produce the entrepreneurs?" The Journal of Socio-Economics, 38(3): 484-494.

Phillips, D. J.

2005 "Organizational genealogies and the persistence of gender inequality: The case of Silicon Valley Law firms.” Administrative Science Quarterly, 50(3): 440-472.

Rabe-Hesketh, S., and A. Skrondal

2012 Multilevel and Longitudinal Modelling using Stata. Third Edition, Stata Press.

Rocha, V., A. Carneiro, and C. Varum

2015 "Entry and exit dynamics of nascent business owners." Small Business Economics, 45(1): 63-84. 
Ruef, M., H. E. Aldrich, and N. C. Carter

2003 "The structure of founding teams: Homophily, strong ties, and isolation among US entrepreneurs.” American Sociological Review, 68(2): 195-222.

Scherer, R. F., J. S. Adams, S. S. Carley, and F. A. Wiebe

1989 "Role model performance effects on development of entrepreneurial career preference." Entrepreneurship Theory \& Practice, 13(2): 53-71.

Scott, M., and D. Twomey

1988 “The long-term supply of entrepreneurs: Students' career aspirations in relation to entrepreneurship.” Journal of Small Business Management, 26(1): 5-13.

Shane, S., and D. Cable

2002 "Network ties, reputation, and the financing of new ventures." Management Science, 48(3): 364-381.

Shapiro, E., F. Haseltine, and M. Rowe

1978 "Moving up: Role models, mentors, and the 'patron system'." Sloan Management Review, 6(1): 19-47.

Smith, N., V. Smith, and M. Verner

2013 "Why are so few females promoted into CEO and Vice-President Positions? Danish empirical evidence 1997-2007.” Industrial and Labor Relations Review, 66(2): 380-408.

Sørensen, J. B.

2007 "Bureaucracy and entrepreneurship: Workplace effects on entrepreneurial entry." Administrative Science Quarterly, 52(3): 387-412.

Sørensen, J. B., and M. A. Fassiotto

2011 “Organizations as fonts of entrepreneurship." Organization Science, 22(5): 1322-1331.

Sørensen, J. B., and D. J. Phillips

2011 “Competence and commitment: Employer size and entrepreneurial endurance." Industrial and Corporate Change, 20(5): 1277-1304. 
Sørensen, J. B., and A. J. Sharkey

2014 "Entrepreneurship as a mobility process.” American Sociological Review, 79(2): 328249.

Srivastava, S. B., and E. Sherman

2015 "Agents of change or cogs in the machine? Reexamining the influence of female managers on the gender wage gap.” American Journal of Sociology, 120(6): 1778-1808.

Thébaud, S.

2010 "Gender and entrepreneurship as a career choice: do self-assessments of ability matter?" Social Psychology Quarterly, 73(3): 288-304.

Thébaud, S.

2015 "Business as Plan B: Institutional foundations of gender inequality in entrepreneurship across 24 industrialized countries.” Administrative Science Quarterly, 60(4): 671-711.

Wilson, F., J. Kickul, and D. Marlino

2007 "Gender, entrepreneurial self-efficacy, and entrepreneurial career intentions: Implications for entrepreneurship education”, Entrepreneurship: Theory and Practice, 31(3): 387-406.

Woodcock, S. D.

2015 “Match effects.” Research in Economics, 69(1): 100-121. 


\section{TABLES}

Table 1. Summary statistics at the worker-level, according to their decision to enter entrepreneurship ${ }^{\text {a }}$

\begin{tabular}{ccccc}
\hline $\begin{array}{c}\text { (I) Future } \\
\text { entrepreneurs }\end{array}$ & $\begin{array}{c}\text { (II) Non- } \\
\text { entrepreneurs }\end{array}$ & $\begin{array}{c}\text { Difference } \\
\text { (I-II) }\end{array}$ & $\begin{array}{c}\text { (III) Movers } \\
\text { (not to e-ship) }\end{array}$ & $\begin{array}{c}\text { Difference } \\
\text { (I-III) }\end{array}$ \\
$\mathrm{N}=1,966$ & $\mathrm{~N}=87,223$ & & $\mathrm{~N}=44,368$ &
\end{tabular}

\begin{tabular}{|c|c|c|c|c|c|c|c|}
\hline \multicolumn{8}{|l|}{ Worker characteristics } \\
\hline Female Worker & 0.319 & 0.516 & -0.197 & $* * *$ & 0.522 & -0.203 & $* * *$ \\
\hline Age & 35.20 & 33.08 & 2.129 & $* * *$ & 31.41 & 3.799 & $* * *$ \\
\hline$\leq$ Secondary Education & 0.436 & 0.548 & -0.112 & $* * *$ & 0.573 & -0.137 & $* * *$ \\
\hline Vocational Education & 0.394 & 0.306 & 0.088 & $* * *$ & 0.289 & 0.105 & $* * *$ \\
\hline Short-medium higher education/Bachelor & 0.122 & 0.110 & 0.013 & $* *$ & 0.103 & 0.019 & $* * *$ \\
\hline Master or $\mathrm{PhD}$ & 0.048 & 0.036 & 0.012 & $* * *$ & 0.035 & 0.014 & $* *$ \\
\hline Married & 0.397 & 0.303 & 0.094 & $* * *$ & 0.272 & 0.125 & $* * *$ \\
\hline Nr. of children & 1.012 & 1.041 & -0.028 & & 1.089 & 0.077 & $* *$ \\
\hline Nr. of different workplaces in the past* & 6.447 & 6.015 & 0.432 & $* * *$ & 5.546 & 0.901 & $* * *$ \\
\hline Years in unemployment (cumulative sum) & 1.876 & 1.580 & 0.296 & $* * *$ & 1.511 & 0.365 & $* * *$ \\
\hline \multicolumn{8}{|l|}{ Workplace characteristics } \\
\hline Firm size (log of employment) & 1.825 & 2.785 & -0.960 & $* * *$ & 2.734 & -0.909 & $* * *$ \\
\hline Share of female workers in the workforce & 0.385 & 0.512 & -0.127 & $* * *$ & 0.513 & -0.128 & $* * *$ \\
\hline \multicolumn{8}{|l|}{ Boss characteristics } \\
\hline Boss age & 39.47 & 42.19 & -2.720 & $* * *$ & 41.52 & -2.054 & $* * *$ \\
\hline Female boss & 0.275 & 0.320 & -0.619 & $* * *$ & 0.317 & -0.042 & $* * *$ \\
\hline Number of different workplaces in the past* & 7.720 & 8.339 & -0.045 & $* * *$ & 8.233 & -0.513 & $* * *$ \\
\hline Years in unemployment (cumulative sum) & 1.524 & 1.572 & -0.047 & & 1.554 & -0.030 & \\
\hline Number of different workplaces as a boss & 2.396 & 2.744 & -0.348 & $* * *$ & 2.588 & -0.192 & $* * *$ \\
\hline
\end{tabular}

${ }^{a}$ The statistics refer to the year of an individual's entry in the firm, so "N" means "number of individuals". ${ }^{b}$ It includes all workplaces, including those where the individual had short-term and part-time/secondary jobs. 
Table 2. The role of same gender bosses in entrepreneurial spawning among workers

\begin{tabular}{lllll} 
& $\begin{array}{l}\text { Broader } \\
\text { entrepreneurship } \\
\text { definition }\end{array}$ & $\begin{array}{l}\text { Stricter } \\
\text { entrepreneurship } \\
\text { definition }\end{array}$ & $\begin{array}{l}\text { Broader } \\
\text { entrepreneurship } \\
\text { definition }\end{array}$ & $\begin{array}{l}\text { Stricter } \\
\text { entrepreneurship } \\
\text { definition }\end{array}$ \\
\hline Female Worker & $-1.2011^{* * *}$ & $-1.5840^{* * *}$ & $-1.1001^{* * * *}$ & $-1.2734^{* * *}$ \\
Female Boss & $(0.1269)$ & $(0.2375)$ & $(0.1516)$ & $(0.2885)$ \\
Female Worker*Female Boss & -0.1010 & -0.3268 & & \\
& $(0.1234)$ & $(0.2315)$ & & \\
Same Gender Boss & $0.5631^{* * *}$ & $1.2315^{* * *}$ & & \\
& $(0.1626)$ & $(0.3157)$ & & 0.3032 \\
Female Worker*Same Gender Boss & & & 0.1011 & $(0.2305)$ \\
& & & $(0.1234)$ & $0.6040^{*}$ \\
\hline Number of Observations & 141,776 & 141,776 & 141,776 & $(40.3348)$ \\
Log Likelihood & $-7,917.9$ & $-2,888.8$ & $-7,917.9$ & $-2,888.9$ \\
Boss-level variance & 0.9421 & 0.7790 & 0.9436 & 0.7875 \\
Worker-level variance & 4.1046 & 5.4210 & 3.9686 & 5.3794 \\
\hline
\end{tabular}

Three-level mixed complementary log-logistic model. *,**, and $* * *$ mean significant at $1 \%, 5 \%$, and $10 \%$ levels, respectively. Values in parenthesis are standard errors. All the specifications control for workers' age, education level, marital status, number of children, years of employment experience, years in unemployment, number of different workplaces in the past, current workplace size and industry, gender composition of the workforce, boss' age, boss' unemployment in the past, boss' employment experience and number of previous workplaces as employer. All the specifications also include dummies for years, worker's tenure (i.e., duration in the workplace) and region of residence (there are five main regions in Denmark).

Table 3. Sensitivity analysis

Dependent variable: Employee's entrepreneurship choices - broader definition of entrepreneurship

\begin{tabular}{lllll} 
& $\begin{array}{l}\text { Firms never } \\
\text { changing } \\
\text { boss/founder }\end{array}$ & $\begin{array}{l}\text { Workers displaced } \\
\text { from closed or } \\
\text { downsized firms }\end{array}$ & $\begin{array}{l}\text { Early hired } \\
\text { workers at the } \\
\text { startup }\end{array}$ & $\begin{array}{l}\text { Controlling } \\
\text { for peer } \\
\text { effects }\end{array}$ \\
\hline Female Worker & $-1.3059^{* * *}$ & $-1.2218^{* * *}$ & $-1.1568^{* * *}$ & $-1.0806^{* * *}$ \\
& $(0.1800)$ & $(0.2491)$ & $(0.2204)$ & $(0.1515)$ \\
Same Gender Boss & 0.0085 & 0.1139 & -0.0645 & 0.1282 \\
& $(0.1429)$ & $(0.1995)$ & $(0.1734)$ & $(0.1236)$ \\
Female Worker*Same Gender Boss & $0.4728^{* *}$ & $0.4769^{*}$ & $0.6033^{* *}$ & $0.3277^{* *}$ \\
& $(0.2062)$ & $(0.2830)$ & $(0.2515)$ & $(0.0811)$ \\
\hline Number of Observations & 108,566 & 52,848 & 59,980 & 141,776 \\
Log Likelihood & $-6,864.1$ & $-2,202.2$ & $-3,926.5$ & $-7,868.9$ \\
\hline
\end{tabular}

Results for stricter definition of entrepreneurship are mostly qualitatively similar and are available upon request. *, **, and *** mean significant at $1 \%, 5 \%$, and $10 \%$ levels, respectively. Values in parenthesis are standard errors. All the specifications include the same control variables specified in Table 2, except the last column, where now we include the share of coworkers with previous entrepreneurship experience as an additional control. The estimated contribution of boss heterogeneity to the variance in entrepreneurship rates does not change too much compared to the results previously found in Table 2 for the broader entrepreneurship definition (19\%), being only a bit higher (about 30\%) for the sample of workers coming from closed or downsizing firms. 
Table 4. Moderating factors of the effect of same gender boss on employees' future entrepreneurship choices (Multi-level mixed cloglog models)

\begin{tabular}{|c|c|c|c|c|}
\hline & \multicolumn{2}{|c|}{ Workplace size } & \multicolumn{2}{|c|}{ Share of female co-workers } \\
\hline & $\begin{array}{l}\text { Broader e-ship } \\
\text { definition }\end{array}$ & $\begin{array}{l}\text { Stricter e-ship } \\
\text { definition }\end{array}$ & $\begin{array}{l}\text { Broader e-ship } \\
\text { definition }\end{array}$ & $\begin{array}{l}\text { Stricter e-ship } \\
\text { definition }\end{array}$ \\
\hline Female Worker & $\begin{array}{l}-1.2966 * * * \\
(0.2482)\end{array}$ & $\begin{array}{l}-2.5527 * * * \\
(0.6540)\end{array}$ & $\begin{array}{l}-0.9872 * * * \\
(0.2843)\end{array}$ & $\begin{array}{l}-1.8592 * * * \\
(0.7555)\end{array}$ \\
\hline Same Gender Boss & $\begin{array}{l}-0.1864 \\
(0.1917)\end{array}$ & $\begin{array}{l}-0.4777 \\
(0.4708)\end{array}$ & $\begin{array}{l}-0.2142 \\
(0.1706)\end{array}$ & $\begin{array}{l}-0.1618 \\
(0.4253)\end{array}$ \\
\hline Female Worker*Same Gender Boss & $\begin{array}{l}0.9933 * * * \\
(0.2672)\end{array}$ & $\begin{array}{l}2.4483 * * * \\
(0.6865)\end{array}$ & $\begin{array}{l}1.2548 * * * \\
(0.3994)\end{array}$ & $\begin{array}{l}2.3574 * * * \\
(0.9856)\end{array}$ \\
\hline Firm size & $\begin{array}{l}-0.4664 * * * \\
(0.0670)\end{array}$ & $\begin{array}{l}-0.8641 * * * \\
(0.1946)\end{array}$ & & \\
\hline Female Worker*Firm size & $\begin{array}{l}0.0941 \\
(0.0824)\end{array}$ & $\begin{array}{l}0.4054 * \\
(0.2385)\end{array}$ & & \\
\hline Same Gender Boss*Firm size & $\begin{array}{l}0.1436^{* *} \\
(0.0692)\end{array}$ & $\begin{array}{l}0.4859 * * * \\
(0.1983)\end{array}$ & & \\
\hline Female Worker*Same Gender Boss*Firm size & $\begin{array}{l}-0.3251 * * * \\
(0.0956)\end{array}$ & $\begin{array}{l}-0.8475 * * * \\
(0.2664)\end{array}$ & & \\
\hline Share of female workers & & & $\begin{array}{l}-0.5684 * \\
(0.3423)\end{array}$ & $\begin{array}{l}-1.3586 \\
(0.9102)\end{array}$ \\
\hline Female Worker*Share of female workers & & & $\begin{array}{l}0.0786 \\
(0.4622)\end{array}$ & $\begin{array}{l}0.7920 \\
(1.2377)\end{array}$ \\
\hline Same Gender Boss*Share of female workers & & & $\begin{array}{l}1.1638 * * * \\
(0.3719)\end{array}$ & $\begin{array}{l}2.2206 * * \\
(0.9705)\end{array}$ \\
\hline $\begin{array}{l}\text { Female Worker*Same Gender Boss*Share of } \\
\text { female workers }\end{array}$ & & & $\begin{array}{l}-1.8300^{* * *} \\
(0.5784)\end{array}$ & $\begin{array}{l}-3.2673 * * \\
(1.4698)\end{array}$ \\
\hline Number of Observations & 141,776 & 141,776 & 141,776 & 141,776 \\
\hline Log Likelihood & $-7,942.9$ & $-2,875.3$ & $-7,939.7$ & $-2,877.1$ \\
\hline
\end{tabular}

$*$,**, and *** mean significant at $1 \%, 5 \%$, and $10 \%$ levels, respectively. Values in parenthesis are standard errors. All the specifications include the same control variables specified in Table 2. 
Table 5. The effect of other worker-boss similarities on employees' future entrepreneurship choices (Multi-level mixed cloglog models)

\begin{tabular}{|c|c|c|c|c|}
\hline & \multicolumn{2}{|c|}{ Age similarity } & \multicolumn{2}{|c|}{ Education background similarity } \\
\hline & $\begin{array}{l}\text { Broader e-ship } \\
\text { definition }\end{array}$ & $\begin{array}{l}\text { Stricter e-ship } \\
\text { definition }\end{array}$ & $\begin{array}{l}\text { Broader e-ship } \\
\text { definition }\end{array}$ & $\begin{array}{l}\text { Stricter e-ship } \\
\text { definition }\end{array}$ \\
\hline \multirow[t]{2}{*}{ Female Worker } & $-1.1716^{* * *}$ & $-1.9384 * * *$ & $-1.2156 * * *$ & $-2.1254 * * *$ \\
\hline & $(0.1538)$ & $(0.4130)$ & $(0.1567)$ & $(0.4119)$ \\
\hline \multirow[t]{2}{*}{ Same Gender Boss } & 0.1722 & 0.2555 & 0.0454 & 0.3618 \\
\hline & $(0.1690)$ & $(0.4534)$ & $(0.1969)$ & $(0.5340)$ \\
\hline \multirow[t]{2}{*}{ Female Worker*Same Gender Boss } & 0.1638 & $0.4260 *$ & $0.4030 * *$ & $1.0319 * * *$ \\
\hline & $(0.1478)$ & $(0.2670)$ & $(0.1597)$ & $(0.3813)$ \\
\hline \multirow[t]{2}{*}{ Worker-Boss similar age } & 0.0228 & 0.1846 & & \\
\hline & $(0.1322)$ & $(0.3586)$ & & \\
\hline \multirow[t]{2}{*}{ Female Worker*Worker-Boss similar age } & $0.2731 *$ & 0.6676 & & \\
\hline & $(0.1607)$ & $(0.4579)$ & & \\
\hline \multirow{2}{*}{$\begin{array}{l}\text { Female Worker*Same Gender Boss* Worker-Boss } \\
\text { similar age }\end{array}$} & $0.3136^{*}$ & $0.8415^{*}$ & & \\
\hline & $(0.1687)$ & $(0.4551)$ & & \\
\hline \multirow[t]{2}{*}{ Worker-Boss similar education background } & & & 0.0049 & 0.0187 \\
\hline & & & $(0.1323)$ & $(0.3407)$ \\
\hline \multirow{2}{*}{$\begin{array}{l}\text { Female Worker*Worker-Boss similar education } \\
\text { background }\end{array}$} & & & $0.2928 *$ & 0.6735 \\
\hline & & & $(0.1793)$ & $(0.4758)$ \\
\hline \multirow{2}{*}{$\begin{array}{l}\text { Female Worker*Same Gender Boss* Worker-Boss } \\
\text { similar education background }\end{array}$} & & & $0.4457 * *$ & $1.6546 * * *$ \\
\hline & & & $(0.1959)$ & $(0.5338)$ \\
\hline Number of Observations & 141,776 & 141,776 & 131,020 & 141,776 \\
\hline Log Likelihood & $-7,946.1$ & $-2,874.0$ & $-7,498.0$ & $-2,666.2$ \\
\hline
\end{tabular}

$*$, **, and $* * *$ mean significant at $1 \%, 5 \%$, and $10 \%$ levels, respectively. Values in parenthesis are robust standard errors. All the specifications include the same control variables specified in Table 2.

Table 6. Testing the validity of the "queen bee" mechanism (Multi-level mixed models)

\begin{tabular}{llll}
\hline & $\begin{array}{l}\text { Probability of } \\
\text { moving to another } \\
\text { job }\end{array}$ & $\begin{array}{l}\text { Probability of } \\
\text { moving to } \\
\text { unemployment }\end{array}$ & $\begin{array}{l}\text { Hourly wages } \\
(\log )\end{array}$ \\
\hline Female Worker & $\begin{array}{l}0.0673 * * * \\
(0.0189)\end{array}$ & 0.0535 & $-0.1028^{* * *}$ \\
Female Boss & $0.1049 * * *$ & $(0.0778)$ & $-0.0056)$ \\
Female Worker*Female Boss & $(0.0235)$ & $0.2501 * * *$ & $(0.0112)$ \\
& $-0.1059 * * *$ & $(0.0892)$ & $0.0305 * * *$ \\
\hline Number of Observations & $(0.0279)$ & $-0.2841 * * *$ & $(0.0094)$ \\
\hline Log Likelihood & 141,776 & $(0.1090)$ & 106,104 \\
\hline
\end{tabular}

$*$, **, and *** mean significant at $1 \%, 5 \%$, and $10 \%$ levels, respectively. Values in parenthesis are standard errors. All the specifications include the same control variables specified in Table 2. The first two-columns are three-level mixed cloglog models for the probability of leaving the current workplace towards another job and unemployment, respectively. The estimated boss-level variance accounts for $9 \%$ and $22 \%$ of the total variance in worker's probability of moving to another job and to unemployment, respectively. The last column is a three-level mixed linear model for hourly wages. Individuals reporting zero wages were excluded from the estimation. The estimated contribution of boss heterogeneity to wages' variation is about $32 \%$. Estimated worker and boss variances are omitted to save space, being available upon request. 


\section{Appendix}

Table A.I. Summary statistics at the worker-level, according to their gender and decision to enter entrepreneurship ${ }^{\text {a }}$

\begin{tabular}{|c|c|c|c|c|c|c|c|c|}
\hline & \multirow{2}{*}{\multicolumn{4}{|c|}{ Men }} & \multirow{2}{*}{\multicolumn{4}{|c|}{ Women }} \\
\hline & & & & & & & & \\
\hline & \multirow{2}{*}{$\begin{array}{c}\begin{array}{c}\text { Future } \\
\text { entrepreneurs }\end{array} \\
\mathrm{N}=1,349 \\
\end{array}$} & \multirow{2}{*}{$\begin{array}{c}\text { Non- } \\
\text {-entrepreneurs } \\
\mathrm{N}=42,217 \\
\end{array}$} & \multicolumn{2}{|c|}{ Difference } & \multirow{2}{*}{$\begin{array}{c}\text { Future } \\
\text { entrepreneurs } \\
\mathrm{N}=617 \\
\end{array}$} & \multirow{2}{*}{$\begin{array}{c}\text { Non- } \\
\text {-entrepreneurs } \\
\mathrm{N}=45,006 \\
\end{array}$} & \multicolumn{2}{|c|}{ Difference } \\
\hline & & & & & & & & \\
\hline \multicolumn{9}{|l|}{ Worker characteristics } \\
\hline Age & 34.56 & 33.31 & 1.253 & $* * *$ & 36.58 & 32.86 & 3.724 & $* * *$ \\
\hline$\leq$ Secondary Education & 0.478 & 0.551 & -0.073 & $* * *$ & 0.355 & 0.545 & -0.190 & $* * *$ \\
\hline Vocational Education & 0.397 & 0.323 & 0.074 & $* * *$ & 0.388 & 0.291 & 0.096 & $* * *$ \\
\hline Short-medium higher education/Bachelor & 0.085 & 0.086 & 0.001 & & 0.193 & 0.130 & 0.062 & $* * *$ \\
\hline Master or $\mathrm{PhD}$ & 0.039 & 0.040 & -0.001 & & 0.066 & 0.033 & 0.032 & $* * *$ \\
\hline Married & 0.378 & 0.285 & 0.093 & $* * *$ & 0.438 & 0.319 & 0.119 & $* * *$ \\
\hline Number of children & 0.979 & 0.945 & 0.034 & & 1.083 & 1.129 & -0.046 & \\
\hline Nr. of different workplaces in the past ${ }^{b}$ & 6.388 & 6.282 & 0.105 & & 6.573 & 5.764 & 0.809 & $* * *$ \\
\hline Years in unemployment (cumulative sum) & 1.754 & 1.544 & 0.210 & $* * *$ & 2.136 & 1.613 & 0.523 & $* * *$ \\
\hline \multicolumn{9}{|l|}{ Workplace characteristics } \\
\hline Firm size (log of employment) & 1.746 & 2.605 & -0.858 & $* * *$ & 1.992 & 2.954 & -0.962 & $* * *$ \\
\hline Share of female workers in the workforce & 0.182 & 0.248 & -0.066 & $* * *$ & 0.818 & 0.760 & 0.058 & $* * *$ \\
\hline \multicolumn{9}{|l|}{ Boss characteristics } \\
\hline Boss age & 38.65 & 41.33 & -2.681 & $* * *$ & 41.21 & 42.99 & -1.780 & $* * *$ \\
\hline Female boss & 0.152 & 0.172 & -0.019 & $* *$ & 0.537 & 0.459 & 0.078 & $* * *$ \\
\hline Nr. of different workplaces in the past ${ }^{b}$ & 7.493 & 8.401 & -0.908 & $* * *$ & 8.204 & 8.282 & -0.077 & \\
\hline Years in unemployment (cumulative sum) & 1.508 & 1.515 & -0.007 & & 1.559 & 1.625 & -0.066 & \\
\hline Number of different workplaces as a boss & 2.324 & 2.695 & -0.371 & $* * *$ & 2.551 & 2.790 & -0.240 & $* * *$ \\
\hline
\end{tabular}

"number of individuals".

${ }^{\mathrm{b}}$ It includes all workplaces, including those where the individual had short-term and part-time/secondary jobs. 
Table A.II. Industry-distribution of workplaces founded by men and women

Female bosses

Wholesale and retail trade

$25,7 \%$

Accommodation and food service activities

$21,2 \%$

Other technical business services

$13,0 \%$

Educational support activities and health care services

$10,0 \%$

Sports, amusement and recreation activities

$6,3 \%$

Primary sector (total)

$4,4 \%$

Construction

$4,3 \%$

Manufacturing industries (total)

$2,4 \%$

Repair of personal goods

$2,4 \%$

Business consultancy activities

$2,0 \%$

Other services*

$8,1 \%$

Total (4,036 newly founded workplaces)

$100 \%$

* Services where the share of female-owned workplaces is smaller than $2 \%$

\section{Male bosses}

Wholesale and retail trade

$14,9 \%$

Construction

$14,7 \%$

Accommodation and food service activities

$14,1 \%$

Agriculture and horticulture

$13,2 \%$

Other technical business services

$10,8 \%$

Transport and storage services

$7,5 \%$

Manufacturing industries

$5,1 \%$

Educational support activities and health care services

$4,5 \%$

Business consultancy activities

$3,3 \%$

Other primary sector activities

$1,4 \%$

Other services*

$10,6 \%$

Total (9,895 newly founded workplaces)

$100 \%$

* Services where the share of male-owned workplaces is smaller than $2 \%$ 